\title{
LETTER FROM THE FIRST TRANSLATION'S IMPRIMATUR
}

\author{
Metropolitan Mor Severius of the Knanaya Diocese of \\ the Malankara Syrian Church
}

(Seal)

No. 257

Greetings to the Layman Joseph Onattu of our Parish of Chingavanam.

Dearly beloved! After having had the books you sent of the Biography of the Holy Mother of God and Notes to the Study of the Holy Bible checked against the original by our Honourable Vicar General and he having expressed the opinion that they are true to the original, permission is hereby granted for their publication. May all those who use these two books with reverence receive God's blessings continually. May the blessings and mercy of our Saviour Jesus the Messiah be upon all of you in abundance, Amen.

On the $27^{\text {th }}$ day of the Month of Dhanu of the year 1925

from Valiapally of Kottayam

(signature) 
